\title{
Usefulness of the analysis of the average ridge width of fingerprints in archaeological research
}

\author{
Daria Gromnicka, Bartosz Wałecki \\ Department of Anthropology, Institute of Environmental Biology, \\ Wrocław University of Environmental and Life Sciences
}

ABSTRACT: Skin ridges (dermatoglyphs or fingerprints) are a characteristic pattern of sulci on the skin of primates which appear on the entire hand palm and on the soles of the feet. Fingerprints are unique, irremovable and invariable which allows bio-identification of specific individuals. The aim of the study was to investigate the usefulness of the analysis of the average width of the skin ridges in archaeological research by analyzing the foot and hand prints found on 7 artifacts dating from the Middle Ages.

An attempt was made to describe the preserved skin slate prints, as well as details of the construction of the prints. The fingers used in forming the pottery were recognized. Attempts were made to read the context of individual impressions. In the study, the following features were analyzed: legibility and suitability of the left imprint for the analysis, the possibility of determining the type of figures (whorls, loops, archs), the possibility of determining the minutiae, the density of the skin ridges left on the surface of the ceramics and the width of the skin ridges left on the surface of the ceramics. The classification of fingerprint minutiae proposed by Czesław Grzeszyk (1970) was used as well as classification of epidermal ridges peoposed by Lestrange (1953) and modified by Bochenska (1964) and Rogucka (1968).

Analysis of the material allowed to conclude that imprints left on building ceramics can be as useful as those imprinted on utilitarian ceramics, despite differences in the composition of the raw material used in production. However, they require more skill to examine, as the impressions are often incomplete which may be related to the fillers added to the mass. Minutiae were evident on the impressions examined, and single bifurcation was the most common form. The tactile figure most commonly found on the fingertip impressions was the loop. It was not possible to delineate Galton lines due to the wiping of the triple ray. Due to the high illegibility of the prints, it was assumed with a high degree of uncertainty that the fingerprints belonged to adults, but the gender could not be determined. Noteworthy were the prints printed on the brick belonging to children. On the mentioned artifact, there is a footprint of a child aged 1-3 years and a handprint of a crawling infant, which allowed us to conclude that the children were under the care of craftsmen.

KEY WORDs: average ridge width, epidermal ridges, archeology, fingerprints, dermatoglyphs, derma 


\section{Introduction}

Epidermal ridges, also known as dermatoglyphs or fingerprints, are a characteristic pattern of sulcion the skin of mammals belonging to the group of Primates. They appear on the fingertips, as well as on the entire palmar surface or on the soles of the feet. Human fingerprints are located on the largest organ of the body - the skin (Latin: cutis, Greek: derma). Montagna and Parakkal (1974) define human skin as "the monumental façade of the human body." The skin is also an organ which possesses a significant diversification of morphological structures (including epidermal ridges). This in turn, enables bio-identification (Montagna and Parakkal 1974).

The aim of the research was to see if footprints and hand prints left on medieval building ceramics might be used to analyze the organization and working conditions of craftspeople. There was an attempt to describe preserved imprints of the skin ridges, as well as the details of the prints' structure. Then, based on the prints left, efforts were made to determine the sex and age of the fingerprint owner. First, the paper provides the basic information essential for futher understanding of the analysis of epidermal ridges. Some basic information about the structure of the skin are provided along with short historical overview of the research on dermatoglyphs. The use of dermatoglyphs in dactyloscopy is also described, taking into consideration the quantitative features of the dermatoglyphs and their role in determining sex and age of particular individuals. The secoond part of the paper provides information on the research on footprints and hand prints left on medieval building ceramics. The aim was to determine how they might be used to analyze the organization and working conditions of craftspeople and how the analysis of the average ridge width of fingerprints may be used to determine sex and age of the owner of the imprints.

\section{Structure of the skin}

Human skin is made up of different types of cells that perform different functions. The skin consists of three main layers. The epidermis is on the outer surface, and the dermis underneath it. Below the dermis there is the third major layer, a fatty layer of varying thickness, beneath which there is a discontinuous flat flap of skeletal muscle that separates the rest of the body's tissues from the integument (Wooi and Lau 2015) (Fig. 1). In turn, the epidermis itself can be further subdivided from the outside to the inside into the horny layer (stratum corneum), granular layer (stratum granulosum), clear layer (stratum lucidum), prickle cell layer (stratum spinosum) and basal layer (stratum basale, also known as stratum germinativum) (Wooi and Lau 2015). The reproductive layer (stratum germinativum) is responsible for the constant renewal of the epidermis, as this is the place where the cells replicate (Moszczyński 1997).

It is on the surface of the hands and feet that the characteristic sulcis, associated with the presence of fingerprints, are distinguishable. The part of the skin where the fingerprints are visible is called friction skin. The dermis of the hands and feet have "prominences in the form of double rows of pimple-like forms" (Moszczyński 1997). These protrusions 
are skin papillas, and each double row of these is located under a furrow that is found between two fingerprints on the epidermis. On the surface of the fingerprints, there are also pores, i.e. numerous holes through which sweat escapes. The height of the fingerprints varies from 0.1 to $0.4 \mathrm{~mm}$ and depends, among other things, on sex, age, height and body composition. In turn, the width of these lines ranges from 0.2 to $0.7 \mathrm{~mm}$ (Moszczyński 1997).

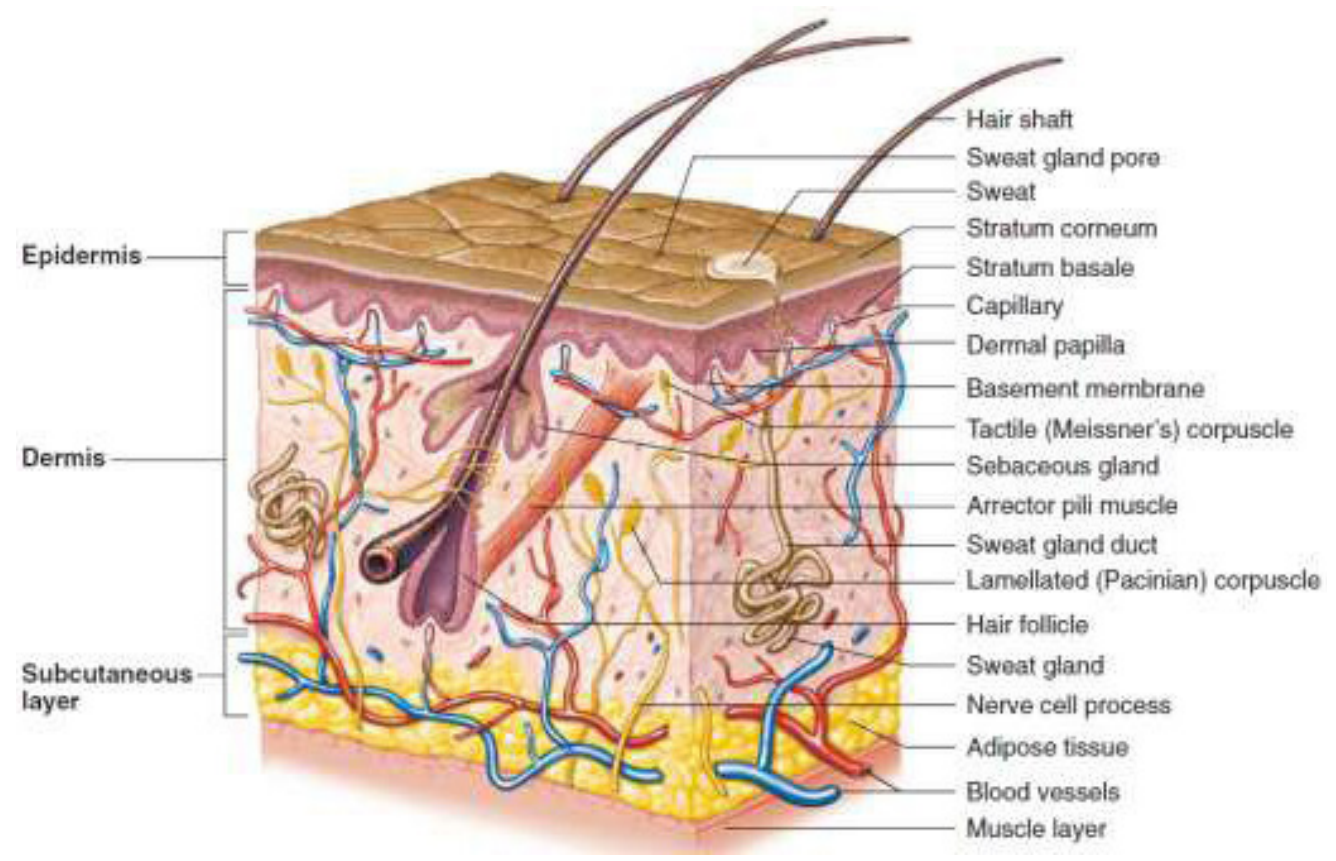

Fig. 1. A cross-sectional representation of human skin (Shier et al. 2010).

Epidermal ridges start to be formed around the seventeenth week of gestational age. In the later stages of life, they may increase in size, but their shape remains unchanged. Importantly, however, fingerprints may be deformed or rubbed off under the influence of various factors, such as physical work, local lesions such as clavi or malignancies. These factors can lead to slight blurring of the ridges and minutiae ${ }^{1}$ (Grzeszyk 1992). An ex- ample of this is by Grzeszyk (1992) who describes the research of Welker, who took his fingerprints and repeated this procedure after 41 years. This experiment showed that the prints, after such a period of time, differed only in the average width of the ridges, while the overall texture did not change. This confirms that the ridges themselves are immutable, while their width may actually alter over the years (Fig. 2).

1 Major features of a fingerprint. 


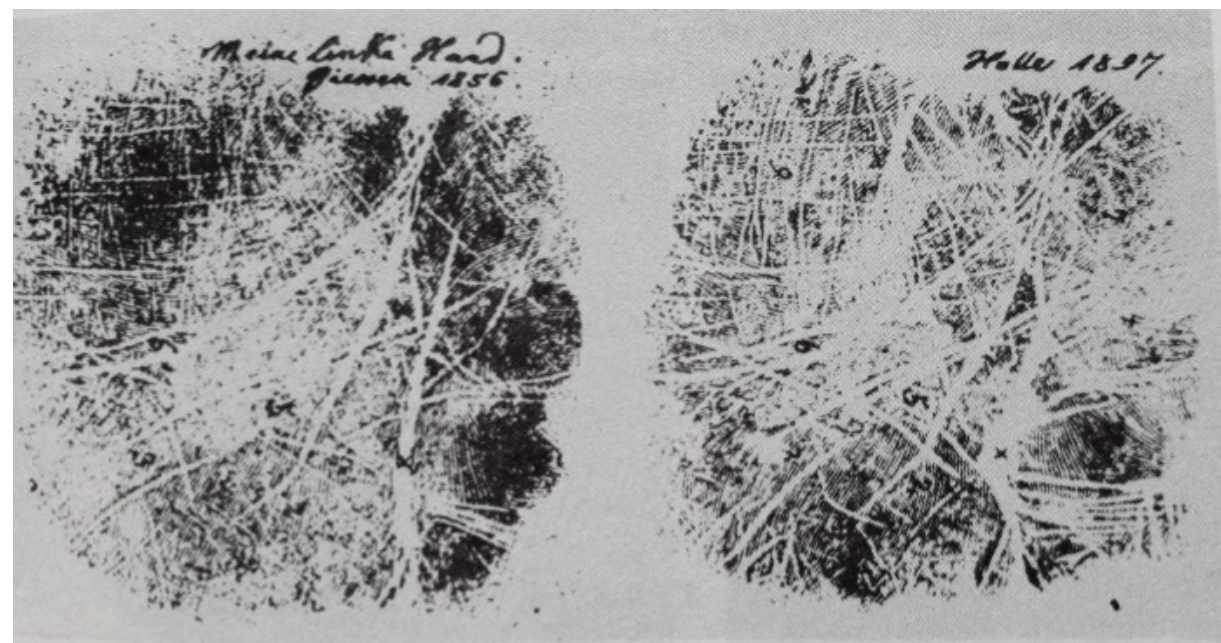

Fig. 2. Imprint of Walker's left hand at the age of 34 (1856) and at the age of 75 (1897) (Grzeszczyk 1992).

\section{Historical overview}

Identifying individuals by fingerprinting has become common practice today and serves as an invaluable tool for identifying people all over the world. This applies both to law enforcement, forensics and archaeological research, but also to large-scale automatic fingerprint identification systems such as devices (e.g. smartphones) or services with access control (e.g. electronic banking). However, it is worth noting that fingerprints and handprints were used as means of identification already in early cultures (Szczepański 2019).

The first observed examples of dermatoglyphs date back to the Neolithic period. The oldest discovered prints are petroglyphs - prehistoric paintings carved in the rocks (Szczepański 2019). An example of such a petroglyph is a drawing of a hand with sulci-like lines found on the shores of a lake in Nova Scotia. Fingerprints can also be found on ceramic products from excavations. These types of imprints are formed accidentally during the formation of these vessels. It has been identified that fingerprints are well preserved on soft clay (Szczepański 2019).

Fingerprints were also intentionally used in the Far East. Fingerprint imprinting on contracts or other legal documents was aimed at identifying individuals and was equivalent to the current use signatures or seals (Szczepański 2019). The unique fingerprint pattern in the form of an imprint on a clay seal, along with the author's name, served to authenticate documents written on bamboo rolls in China during Qin and the Han Dynasties from $221 \mathrm{BC}$ to $220 \mathrm{AD}$. The earliest example of the use of handprints as evidence in a detective investigation is the examination of a burglary site described in a document from the Qin Dynasty (221-206 BC) (Szczepański 2019).

Initially, scientists interested in fingerprints focused more on their structure than on the analysis of possible identification functions. Although many researchers have described the structure of fingerprints, the work of Johannes 
Evangelista Purkinje, professor of the University of Wrocław, Commentatio de Examinae Physiologico Organi Visus er SystematisCutanei (1823), should be particularly emphasized. He was the first who not only described fingerprints but created their scientific classification by distinguishing nine types and patterns of fingerprints existing on fingertips: arches, tents, two types of loops and five types of whorls (Moszczyński 1997). The very foundations of modern dactyloscopy, i.e. the science of dermatoglyphs, began to be developed only during the last two decades of the nineteenth century.

A person who had a great influence on the development of the research on fingerprints was Henry Faulds. Faulds who inspired by prints on prehistoric ceramics, began exploring fingerprints to a large extent. His main work was the discovery of the indestructibility of fingerprints - damaged or removed epidermis, after regeneration, has the same shape of fingerprints as the epidermis prior to being damaged. Currently, the feature of indestructibility, apart from individuality and invariability, is one of the basic features of dermatoglyphs (Faulds 1923).

An important figure in the development of dactyloscopy was Francis Galton. In his research, he proposed a system for classifying fingerprint patterns, dividing them into arches, loops and whorls (Moszczyński 1997). His greatest achievement, however, was demonstrating the durability of fingerprints and proving that changes in their course arise only through damage to the reproductive layer of the epidermis. However, an equally important result of his research was to show that there cannot exist two individuals with an identical pattern of fingerprints, which Galton supported with a mathematical formula. The segment connecting the center of the fingerprint pattern with the delta is now named after him (Galton 1893).

\section{The use of dermatoglyphs in dactyloscopy}

Dactyloscopy studies the skin texture on palms and soles. A fingerprint consists of a set of parallel lines that form a unique pattern for each individual. When observing a imprint, we can distinguish ridges (i.e. lines touching the surface) and valleys (these are the spaces between two ridges) (Machhout 2017). Each fingerprint also has a set of singular (centers and deltas) and local points. While the centers correspond to the locations of the ridges convergence, the deltas correspond to the locations of their divergence (Machhout 2017). From a variety of continuous line layouts, including their beginnings, endings, segments and dots the so-called minutiae are formed, which are also characteristic features of the structure of fingerprints (Machhout 2017). Fingerprint identification and examination itself are based on three basic principles:

- Individuality (uniqueness) - fingerprints are unique for each individual. Therefore, it can be assumed that no two individuals have the same fingerprint pattern. According to Wójcik et al. (2014), fingerprint studies together with statistical studies show that the probability of the appearance of two identical dermatoglyphs is 1 to 64 trillion. Moreover, fingerprints may also differ in individual fingers of the same person. It is this uniqueness that allows for the identification of individual people. For this purpose, the following are used: minutiae (characteristic features of the structure of fingerprints), general arrangement of 
fingerprints, distribution and shape of pores, irregular shape of the edges of fingerprints (Moszczyński 1997).

- Indestructibility (irremovability) - the durability of fingerprints is ensured by the regenerative and replication capacity of cells. This allows the regeneration of fingerprints in exactly the same pattern, despite various types of damage to the epidermis (Moszczyński 1997).

- Invariability - epidermal ridges formed up to the sixth month of life remain unchanged until the death of the individual (Moszczyński 1997).

Despite the fact that fingerprints are characterized by a diverse and unique structure, they can be classified according to specific patterns and configurations. Each area has unique regional and individual structural differences that are not found anywhere else for the same or any other person (Montagna and Parakkal 1974). However, the patterns of the configuration of the ridges and sulci can be grouped according to some common characteristics. For example, it is important to remember that ridges are wider in males than in females (Montagnaand Parakkal 1974). Fingerprints also create recognizable patterns that can be divided into three groups according to their combinations: arches, tent arch patterns (tents), right loop patterns (right loops), left loop patterns (left loops) and whorl patterns (whorls) (Fig. 3) (Stolarek 2008). Thus, dermatoglyphs constitute a peculiar unique personal identification pattern used for identification in dactyloscopy (Fig. 4).
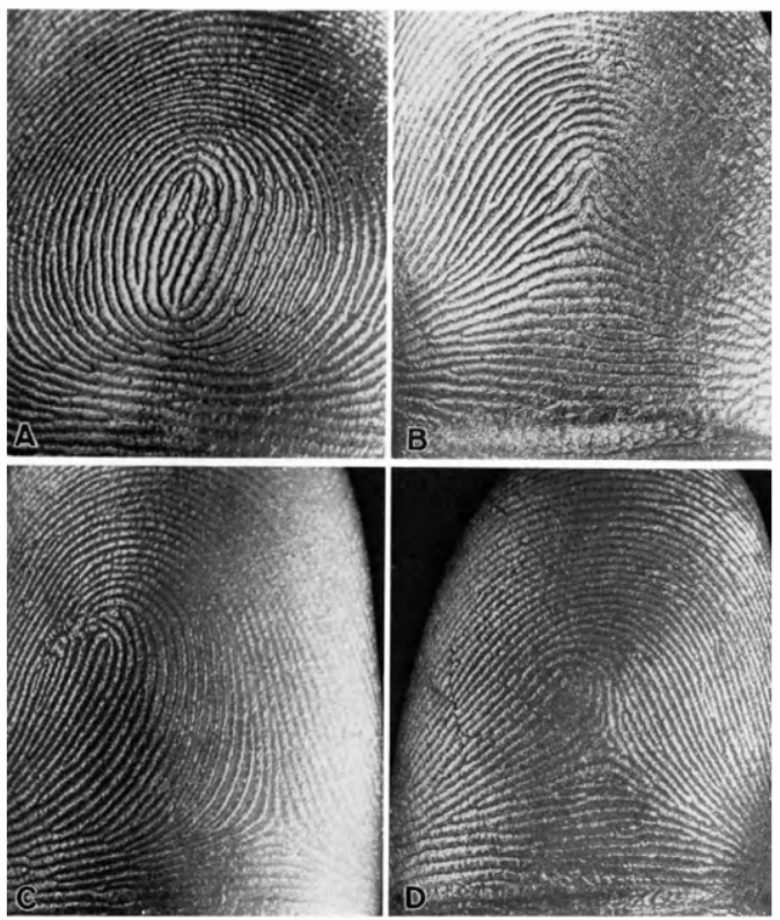

Fig. 3. Major patterns of dermatoglyphics: (A) whorl, (B) arch, (C) loop, (D) combined form (Montagna and Parakkal 1974). 


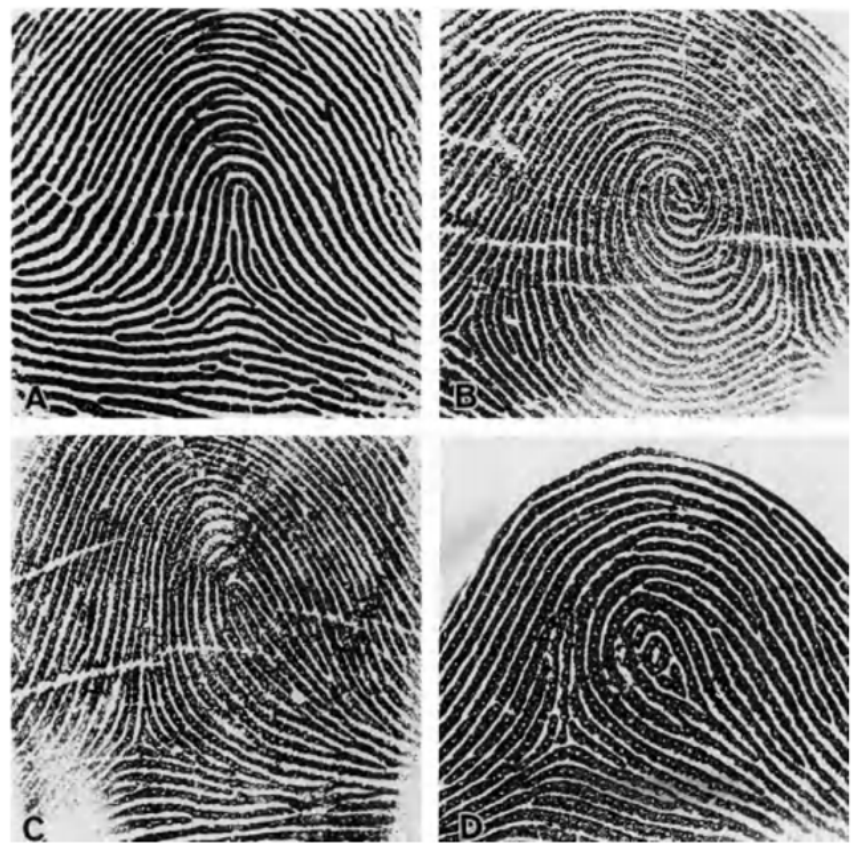

Fig. 4. Fingerprints; the imprints of dermatoglyphics (Montagna and Parakkal 1974).

The quantitative features of the dermatoglyphs are based on the average width and density of the ridges. Both the average width of the skin ridges and their average density depend on the sex and age of the individual. These features are crucial in identifying dermatoglyphs in relation to individuals, as they assist in determining a person's sex and age. Apert from the aging process, fingerprints undergo visual and chemical changes that affect the morphology of the skin ridges (Montagna and Parakkal 1974). The technique of capturing differences between males and females, both in terms of the thickness of the ridges and the distribution of minutiae itself, is morphometry. In the context of research on skin ridges, this technique includes: shape and size analysis, and can be useful for assessing the age of an individual from fingerprints, in particular by identifying and analyzing the average width of ridges that change over the course of life. During adolescence, the ridges expand, which is caused by the increase in body size during progressive ontogenesis. In early adulthood, quantitative characteristics do not increase significantly. Under the influence of involution processes, these averages begin to change again (Alcaraz-Fossoul 2018). Research shows that aging causes narrowing of the ridges and loss of their continuity, while their density increases. In addition, due to aging, the ridges blur and become less visible, which may also be influenced by environmental factors such as the degree of exposure to natural light, 
the type of sweat, temperature and humidity (Alcaraz-Fossoul 2018).

When measuring the width and density of the ridges, the length of the previously determined and measured section and the number of ridges passing through this section is taken into account. On the fingertip, this segment is known as Galton's line which is drawn from the center of the pattern to the triple fork. In the case of whorl patterns, it is usually the line that has the greater number of ridges that is selected, while in the case of an arch pattern, it is a randomly defined section running perpendicular to their course, e.g. $2 \mathrm{~cm}$ long. In the case of measurements on the sole, several sections of a fixed length are marked - e.g. $2 \mathrm{~cm}$ in a few places. These can be the heel surface of the foot and the toe surface of field IV (the surface of the foot place under toes four and five). In the case of measuring the average width of the ridges of the skin, the quotient of the number of ridges and the length of the measured section, given in centimeters, is calculated. However, in measuring the average density of the skin ridges, the quotient of the length of the measured section (given in millimeters) and the number of ridges is used. These measurements are used to determine the sex and age of a person, which is useful in forensic examinations. They can also be useful for archaeological research in order to access more information about the person who made an artefact.

\section{Materials and methods}

Imprints left on building ceramics can tell researchers a lot about the production process itself, as well as about the producers themselves and the organization of their workplace. However, there are not many studies focusing on the analysis of fingerprints left on building materials (Wałecki 2019). The use of the average width of the ridges has been based on research on imprints left on ceramics. The aim of the study was to determine the usefulness of footprints and hand prints left on medieval construction ceramics in the assessment of the organization and conditions of craft work. An attempt was made to describe the preserved imprints of the skin ridges, as well as the details of the structure of the prints. Then, on the basis of the prints left, efforts were made to assess the sex and age of the owner of the fingerprints.

The gathered research material contained seven fragments selected from a collection of medieval bricks. The fragments which were selected contained clear traces of human handprints and footprints. The material was excavated from debris from the former Gomólka Hill in Wrocław, now known as the Anders Hill. The material was cataloged and analyzed at the turn of May and June 2019 (Wałecki 2019).

During the examination of the fingerprints, the following features were analyzed: legibility and suitability of the left imprint for the analysis, the possibility of determining the type of figures (whorls, loops, archs), the possibility of determining the minutiae, the density of the skin ridges left on the surface of the ceramics and the width of the skin ridges left on the surface of the ceramics. The classification of fingerprint minutiae proposed by Czesław Grzeszyk (1970) was used as well as classification of epidermal ridges proposed by Lestrange (1953) and modified by Bochenska (1964) and Rogucka (1968) (Fig. 5, Fig. 6). 
The analysis showed that on artifact no. 1 there are: fragments of fingerprint II, III and IV (Fig. 7). Artifact no. 2 shows fragments of fingerprints II, III and IV (Fig. 8). Artifact no. 3 contained traces of fingers II, III and IV (Fig. 9), while arti- fact no. 4 of fingers II and III (Fig. 10). Artifact no. 5 shows most probably a partial fingerprint of the finger I of the left hand (Fig. 11), while artifact no. 6 shows an imprint of the child's left foot (Fig. 12) (Wałecki 2019).

\begin{tabular}{|c|c|c|c|c|}
\hline \multicolumn{2}{|c|}{ NAZWA MINUCJI } & \multirow{3}{*}{$\begin{array}{c}\text { SYMBOL } \\
\text { I }\end{array}$} & \multirow{2}{*}{\multicolumn{2}{|c|}{ WZÓR }} \\
\hline w języku polskim & w języku lacińskim & & & \\
\hline Początek & Initium & & 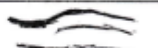 & \\
\hline Zakończenie & Terminatio & $\mathrm{T}$ & $\equiv$ & \\
\hline Rozwidlenie pojedyncze & Bifurcatio simplex & B1 & & \\
\hline Rozwidlenie podwójne & Bifurcatio duplex & B2 & & \\
\hline Rozwidlenie potrójne & Bifurcatio triplex & B3 & $\equiv$ & $\sum$ \\
\hline Złączenie pojedyncze & Iunctio simplex & Inl & & 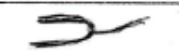 \\
\hline Zlączenie podwójne & Iunctio duplex & $\operatorname{In} 2$ & $>$ & 2 \\
\hline Złączenie potrójne & Iunctio triplex & $\operatorname{In} 3$ & & 3 \\
\hline Haczyk & Unculus & $\mathrm{U}$ & & r \\
\hline Oczko pojedyncze & Ocellus simplex & O1 & & $\infty$ \\
\hline Oczko podwójne & Ocellus duplex & $\mathrm{O} 2$ & D- & $\infty$ \\
\hline Mostek pojedynczy & Ponticulus simplex & P1 & 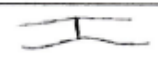 & $=$ \\
\hline Mostek bliźniaczy & Ponticulus gemellus & $\mathrm{Pq}$ & $E$ & 9 \\
\hline Punkt & Punctum & $\mathrm{Pm}$ & 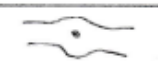 & $\overline{2}$ \\
\hline Odcinek & Segmentum & $\mathrm{S}$ & 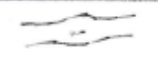 & $=$ \\
\hline Styk boczny & Iunctura laterialis & Ilat & r & 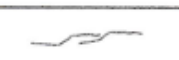 \\
\hline Linia przechodząca & Linea intermittens & $\mathrm{Li}$ & $=\sqrt{-}$ & $=-$ \\
\hline Skrzyžowanie & Decussatio & D & $3 x$ & $\infty$ \\
\hline Trójnóg & Tripus & $\mathrm{Tr}$ & $-\alpha$ & $-\alpha$ \\
\hline Linia szczątkowa & Linea rudimentalis & $\mathrm{Lr}$ & $=-2=$ & $=-\ldots$ \\
\hline Minucja typu „M" „m” & Minutia „M" formis & M & $\Longrightarrow$ & $\Longrightarrow$ \\
\hline
\end{tabular}

Fig. 5. Types of epidermal ridges minutiae on fingertips proposed by Grzeszyk (Moszczyński 1997). 


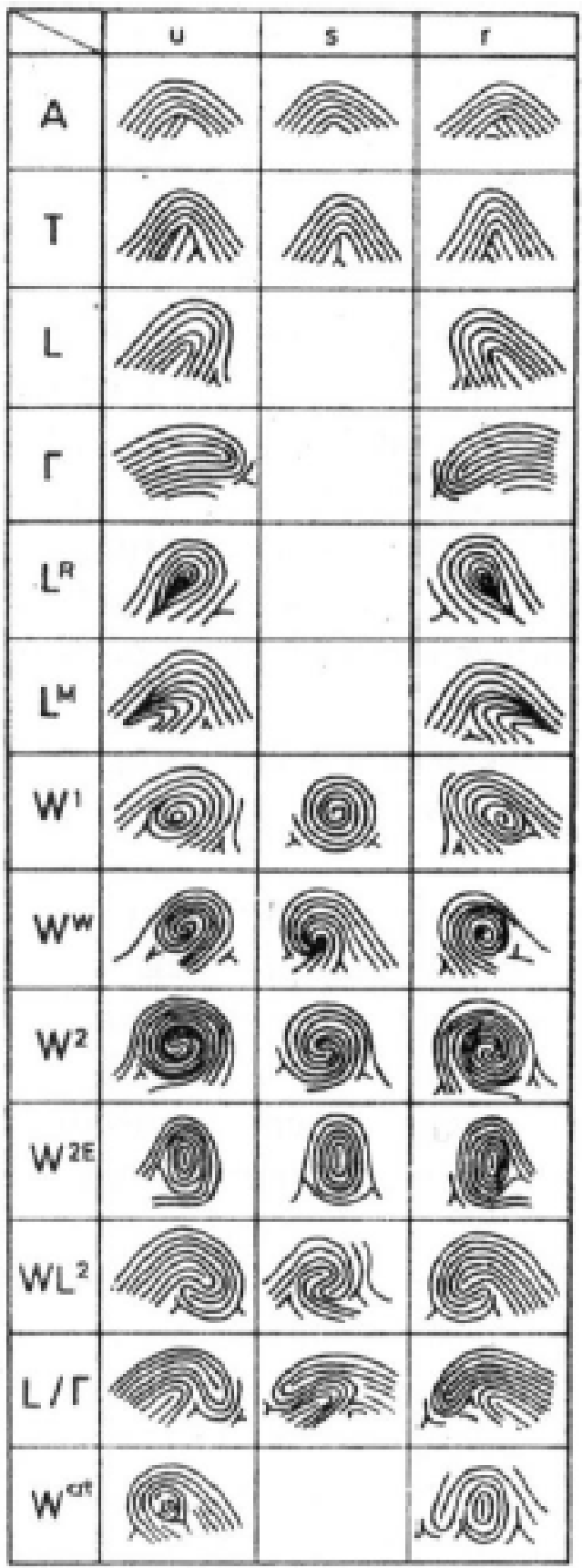

Fig. 6.: Classification of epidermal ridges on fingertips (according to Lestrange 1953 - as modified by Bochenska 1964 and Rogucka 1968) (Grzeszyk 1992). 


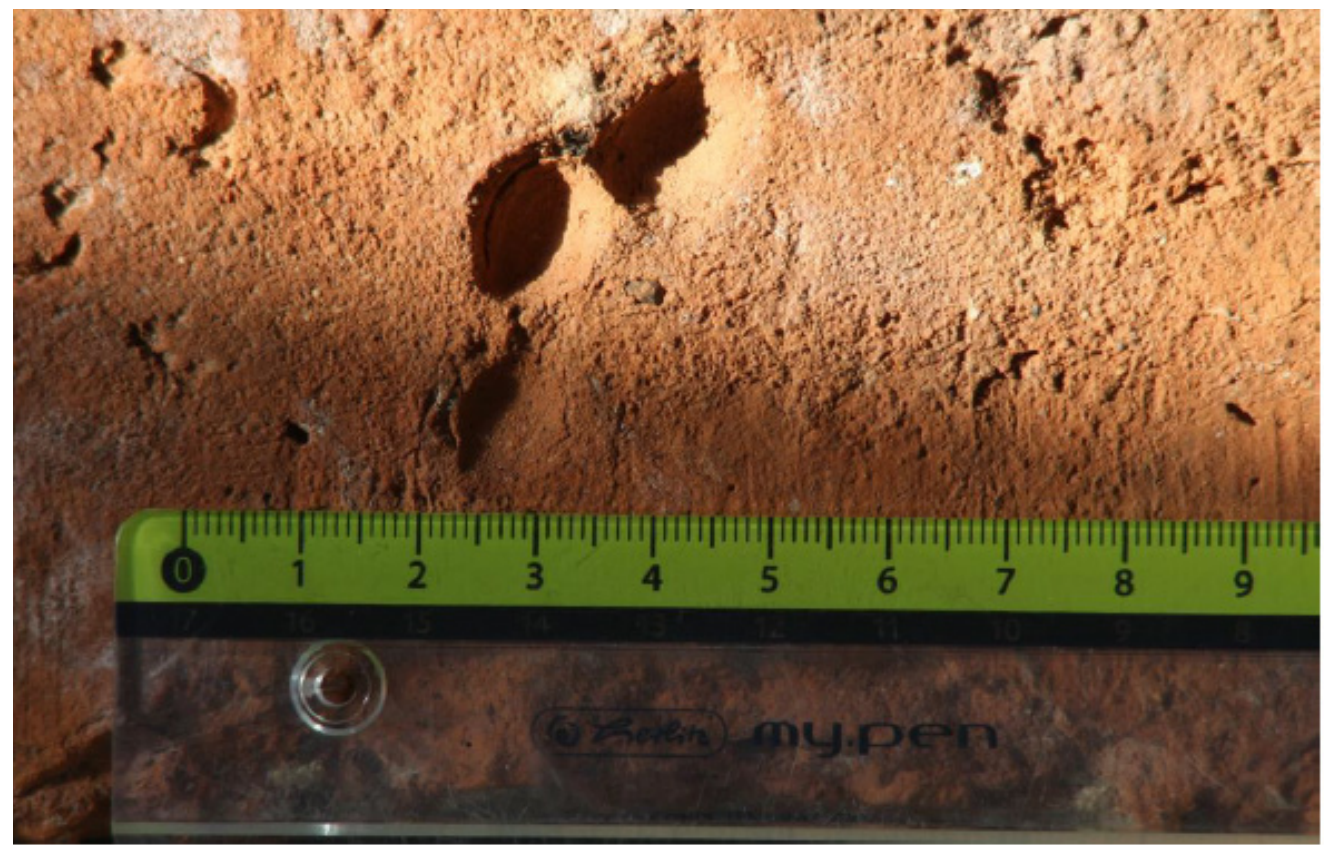

Fig. 7. Image of the artifact no. 1 (Wałecki 2019).

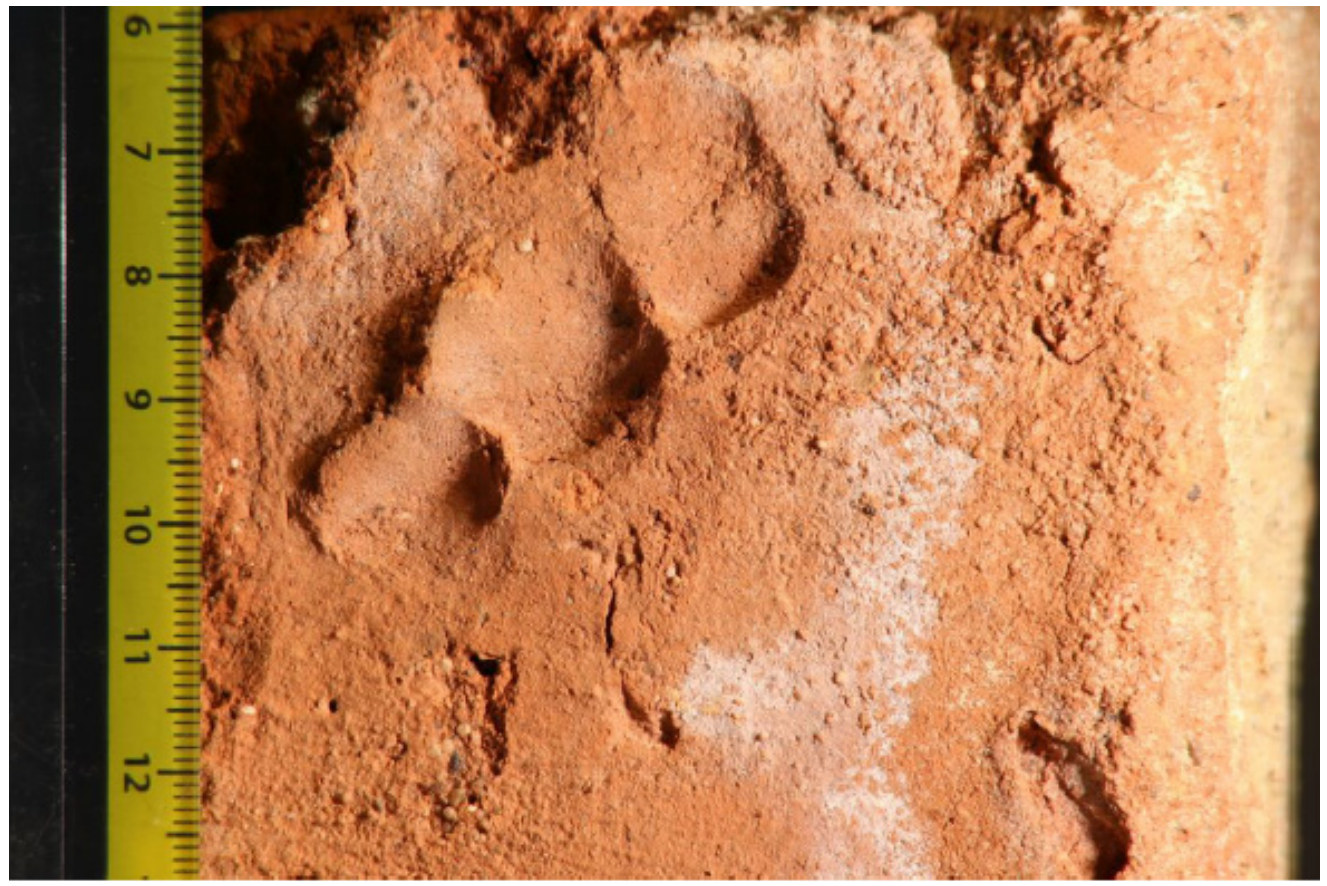

Fig. 8. Image of the artifact no. 2 (Wałecki 2019). 


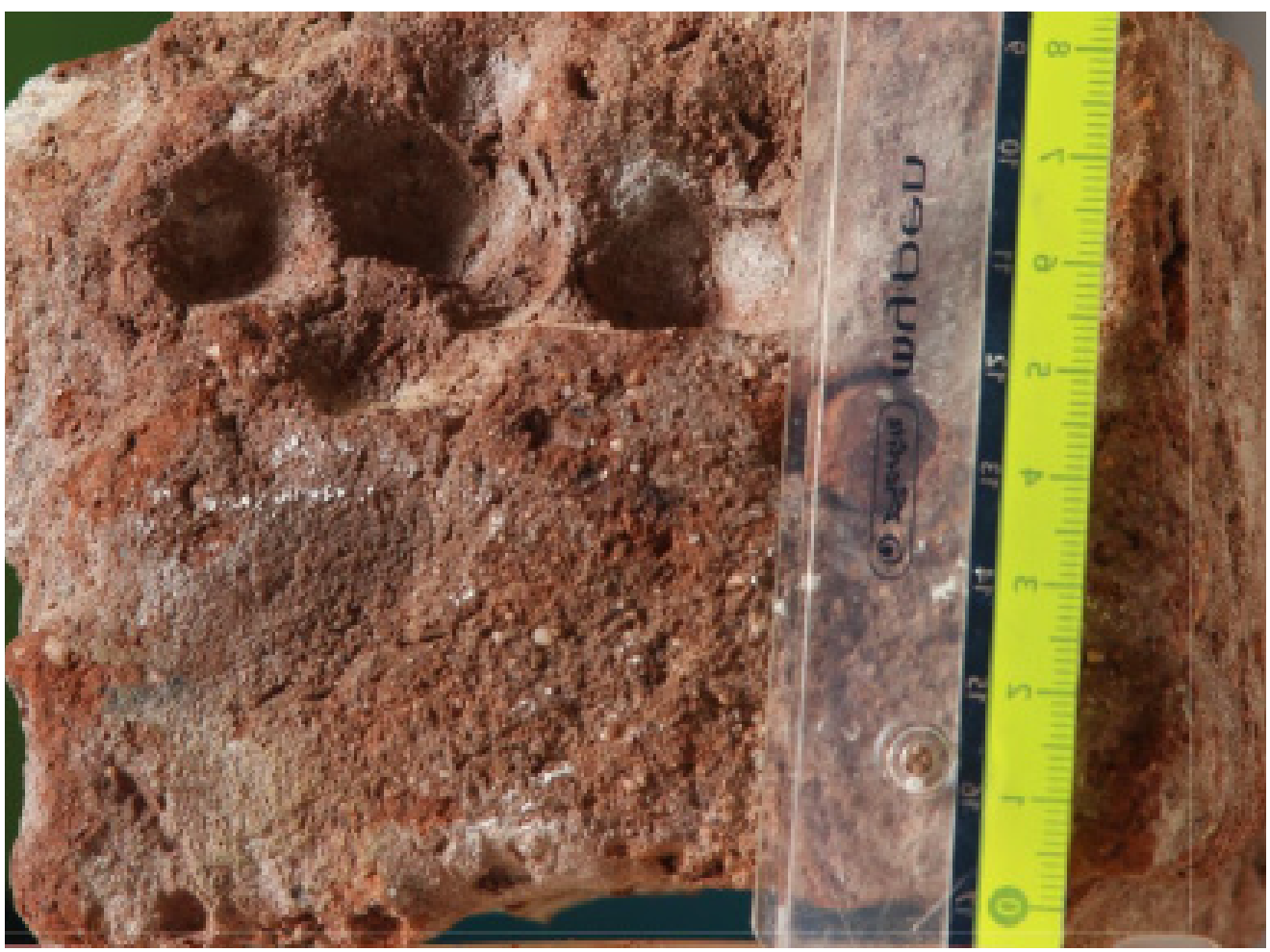

Fig. 9. Image of the artifact no. 3 (Wałecki 2019).

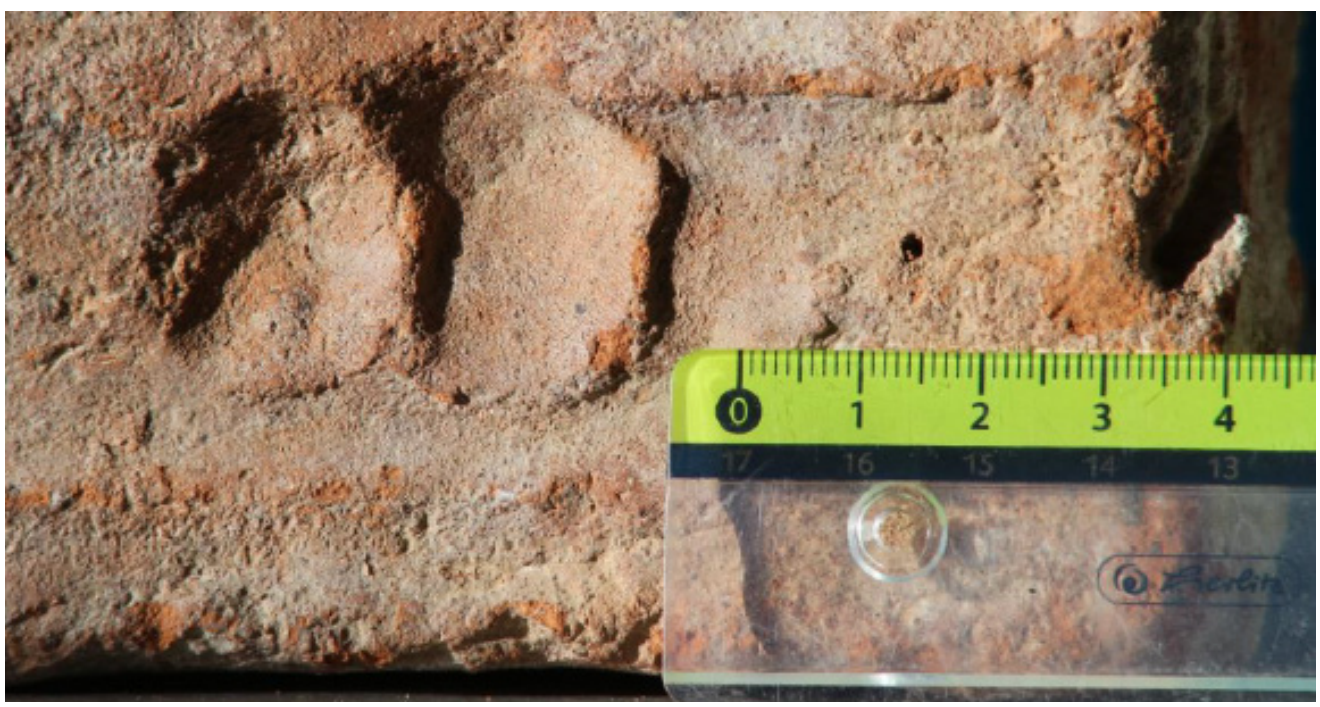

Fig. 10. Image of the artifact no. 4 (Wałecki 2019). 


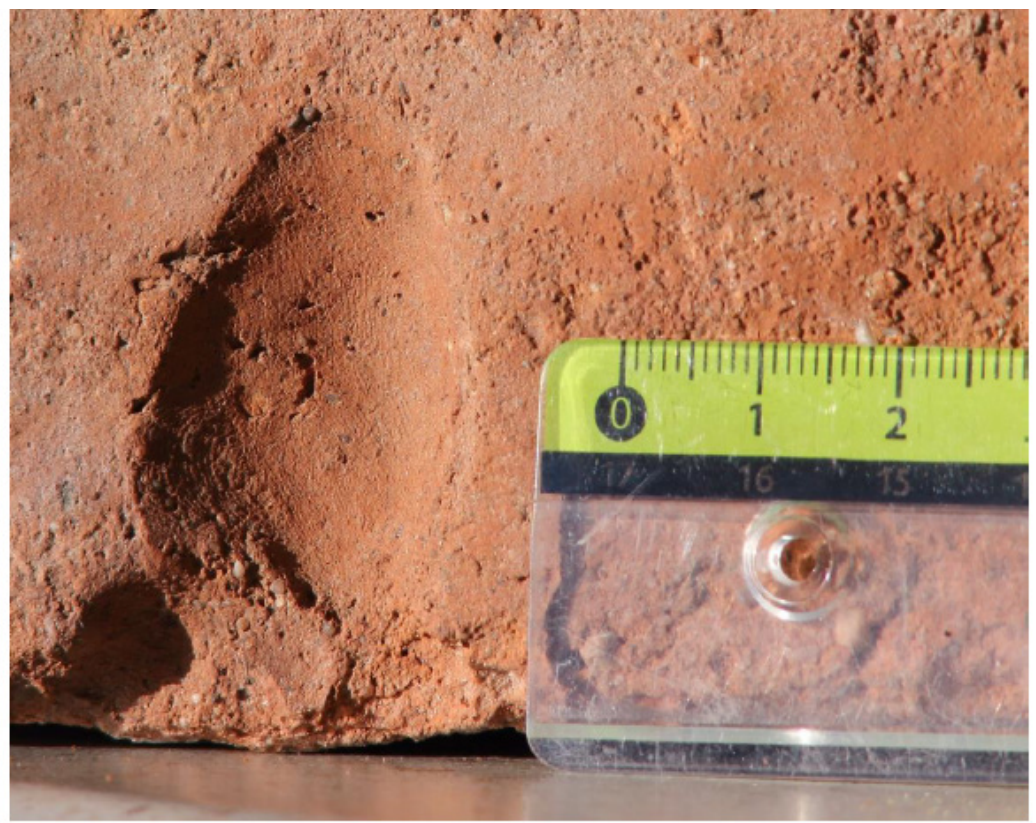

Fig. 11. Image of the artifact no. 5 (Wałecki 2019).

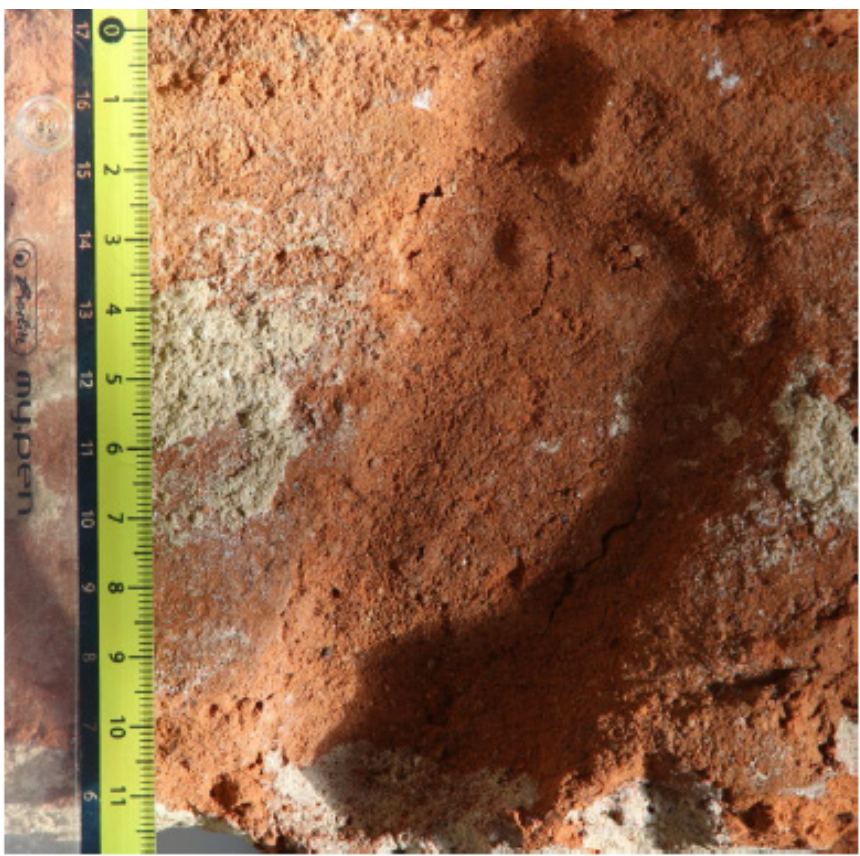

Fig. 12. Image of the artifact no. 6 (Wałecki 2019). 


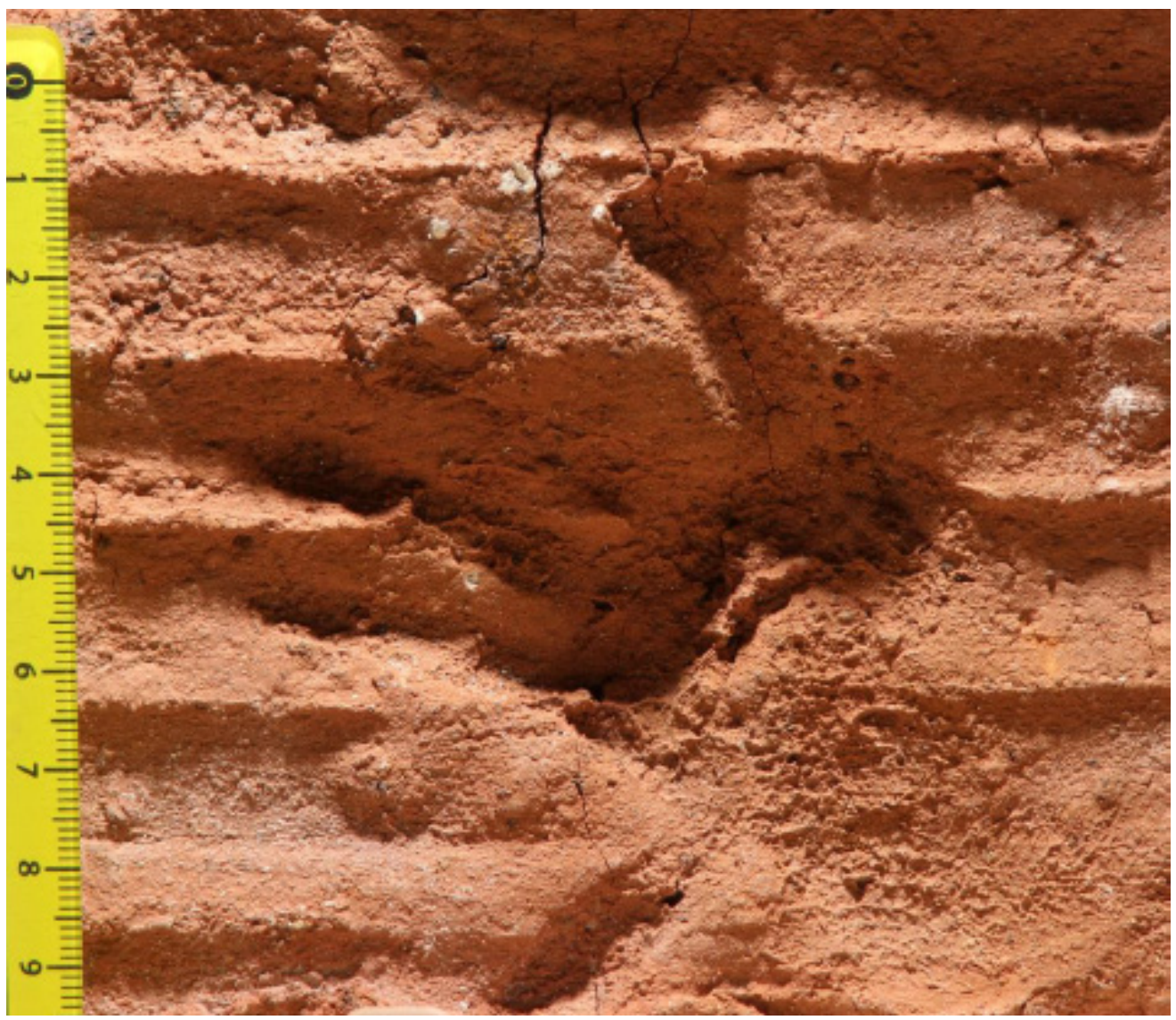

Fig. 13. Image of the artifact no. 7 (Wałecki 2019).

\section{Results}

In the above-mentioned research, only three of the imprints were found to have a $5 \mathrm{~mm}$ section with an undamaged surface of the imprint. On artifact no. 2, fingerprint III, more precisely the fingerprint of the fingertip segment, had 10 skin ridges per $5 \mathrm{~mm}$ segment. Artifact no. 4 and fingerprint III had 9 skin ridges by $5 \mathrm{~mm}$ and artifact no. 5 , most likely showing fingerprint I, had 9 skin ridges by $5 \mathrm{~mm}$ (Table 1). The degree of material shrinkage during dry- ing and firing was not known due to the chemical composition. No information was found on the shrinkage of building ceramics during its manufacture, therefore, it was difficult to determine the age of the craftsmen. If there had been an artifact with several distinct fingerprints from one craftsman, the likelihood of determining the age and sex of the owner of the print would improve. There were too few prints in the study, which severely limited the accurate estimation of the craftsman's sex and age (Wałecki 2019). 
Table 1. Analysis of artifacts

\begin{tabular}{lll}
\hline artifact number & type of the imprint & \multicolumn{1}{c}{ number of skin ridges over $5 \mathrm{~mm}$ section } \\
\hline artifact no. 1 & fingerprint II & $\begin{array}{l}\text { It is not possible to determine the density or width of epider- } \\
\text { mal ridges due to the deficiencies. }\end{array}$ \\
artifact no. 1 & fingerprint III & $\begin{array}{l}\text { It is not possible to determine the density or width of epider- } \\
\text { mal ridges due to the deficiencies }\end{array}$ \\
artifact no. 1 & fingerprint IV & $\begin{array}{l}\text { It is not possible to determine the density or width of epider- } \\
\text { mal ridges due to the deficiencies }\end{array}$ \\
artifact no. 2 & fingerprint II & $\begin{array}{l}\text { It is not possible to determine the density or width of epider- } \\
\text { mal ridges due to the deficiencies }\end{array}$ \\
artifact no. 2 & fingerprint III & $\begin{array}{l}10 \text { skin ridges } \\
\text { artifact no. } 2\end{array}$ \\
fingerprint IV & $\begin{array}{l}\text { The fingerprint is unreadable, was preserved during a move- } \\
\text { ment, making it impossible to read the fingerprint. }\end{array}$ \\
artifact no. 3 & fingerprint II, III, IV & $\begin{array}{l}\text { The imprint represents movement. There is some mortar } \\
\text { residue in the center of the imprint. }\end{array}$ \\
artifact no. 4 & fingerprint II & 6 skin ridges \\
artifact no. 4 & fingerprint III & 9 skin ridges \\
artifact no. 5 & fingerprint I & 9 skin ridges \\
artifact no. 6 & left foot imprint & no traces of skin ridges \\
artifact no. 7 & hand imprint & no traces of skin ridges \\
\hline
\end{tabular}

The analysis showed the following results: While fingerprints of II, III and IV fingers were the most common, it was not found that they belonged to the same person. The most common minutiae in fingerprints was single bifurcation. They were located on fingerprint II and IV on artifact no. 1, fingerprint II on artifact no. 2, fingerprint II and III on artifact no. 4. The prints on artifacts 2 , 4 and 5 were assumed to belong to an adult which was estimated on the basis of the average width of epidermal ridges. It can be concluded that the width of the skin ridges and their distinct fragments probably derived from an adult. From the collected material, it was not possible to unequivocally determine the sex and age of the owners of the prints. The print on artifact number 6 belonged to a child aged 1-3 years. The trace visible on artifact number 7 belonged to a crawling child. The imprint showed the marks made when the hand was torn off. The depth and uneven distribution of the mark indicated that the infant was already able to crawl, which allowed us to assume that the child was between 6 and 12 months old. Artifacts 6 and 7 had prints from two different children, as evidenced by the fact that an imprint on artifact 6 was left by a walking child walking, while imprint on artifact 7 was left by younger, crawling child. Artifact 6 had an imprint of a walking child. Most likely the child was from 1 to 3 years old. The beginning of the transverse arch of the foot is visible, as well as a slight supination (Assuming the supine position or the state of being supine. It was assessed on the basic of the imprint of the foot). This may indicate the correct 
development of the foot and the difficulty of the terrain in which the child had to move in. Artifact 7, on the other hand, contained an imprint of the palm, which was left when the brick was very wet. This is evidenced by the characteristic patterns formed on wet clay immediately after pressing the hand.

In the above study, an important element of the analysis was the average width of the ridges. Even though it was not possible to determine age and sex of the owners of the prints, with the help of these measurements, it was possible to try to determine the age and sex of an individual who left a mark on a given vessel or tool. Moreover, it is definitely possible to state that the analysis of the width of epidermal ridges may be beneficial while trying to discover age and sex of the individual to whom the prints belong to.

In this particular research, there were too few prints which limited the accurate estimate of the sex and age of the individual. Nevertheless, it can be concluded that the thickness of the skin ridges and their clear fragments may indicate an adult. Still, prints on artifacts 2, 4 and 5 pose a problem in sex identification. It should be noted that the interpretation of artifacts is subjective, and the material analyzed due to the fragmented state of preservation makes it difficult to make an unambiguous and certain statement. More materials with better preserved imprints and the examination of the chemical composition of the ceramics would enable a more detailed analysis. The average width of the ridges is in fact a measurement often used in identification and dactyloscopic research in archeology. In scientific works, attention is paid to the correlation between the width of the ridges and the age of individuals.

\section{Discussion}

In 1987, Franaszek and Grzeszyk examined 879 volunteers in terms of a correlation between age and the width of the skin ridges. 444 men and 435 women participated in the study. The respondents were divided according to their age into 10 groups from 7 to 25 years of age and above. It was found that over a distance of $5 \mathrm{~mm}$, the mean numbers of ridges start to differ between women and men from 13 to 14 years of age, and the mean width of the ridges increases with age (Franaszek and Grzeszyk 1987). However, the authors noticed that taller and more strongly built people have wider ridges than shorter people of weaker body composition.

Along with the human growth process which leads to an increase in body size, the skin ridges increase their dimensions (height, length, width), while maintaining their numbers. Depending on the finger we are considering, the width of the ridges will be different. It was found that on the thumbs and on the fingers of the right hand, the skin ridges were wider than on the left hand. On the other hand, women have narrower skin ridges than men. The changes taking place on the ridges of children are most intense during their adolescence, and with the completion of the growth process, the rate of changes taking place on the ridges slows down. The type of food and work performed may slightly increase the size of fingerprints even up to the age of 60 years (e.g. the process of gaining weight results in the increase in body surface and thus, the surface of the palm also increases causing changes in the width of epidermal ridges). It is assumed that the number of skin ridges per $5 \mathrm{~mm}$ ranges from 15 to 18 in children up to 12 years of age. Adults from the age 
of 20 years have $9-10$ skin ridges with a length of $5 \mathrm{~mm}$.

Analysis of the average width of the ridges for dactyloscopic identification in archeology was also used by Králík et al. (2002). They examined a fingerprint left on the statue of Venus of Dolní Věstonice I, which was discovered on July 13, 1925 in Dolní Věstonice, South Moravia (Czechoslovakia at that time) carried out by Karel Absolon. It is a figurine made of fired clay, approx. $11.5 \mathrm{~cm}$ high, depicting a female figure with rounded shapes. The figurine was found in two parts, in the central fireplace in the upper part of the village of Dolni Věstonice. It is dated to the period of the Upper Palaeolithic of the Gravesian Culture, which peaked between 27,000 and 24,000. years ago. Only 75 years after the discovery of the figurine, it was examined from the paleodermatoglyphic perspective, i.e. $\mathrm{x}$-rayed in search of the imprints left on it. Analysis revealed the presence of a fingerprint which was located on the left side of the figure's back, directly above the upper oblique fold, where the left fingerprints were almost parallel to the fold in the figure (Fig. 14). The dimensions of the dermatoglyph were estimated at $3 \mathrm{x} 5 \mathrm{~mm}$. Seven lines were recognized (Králík et al. 2002).

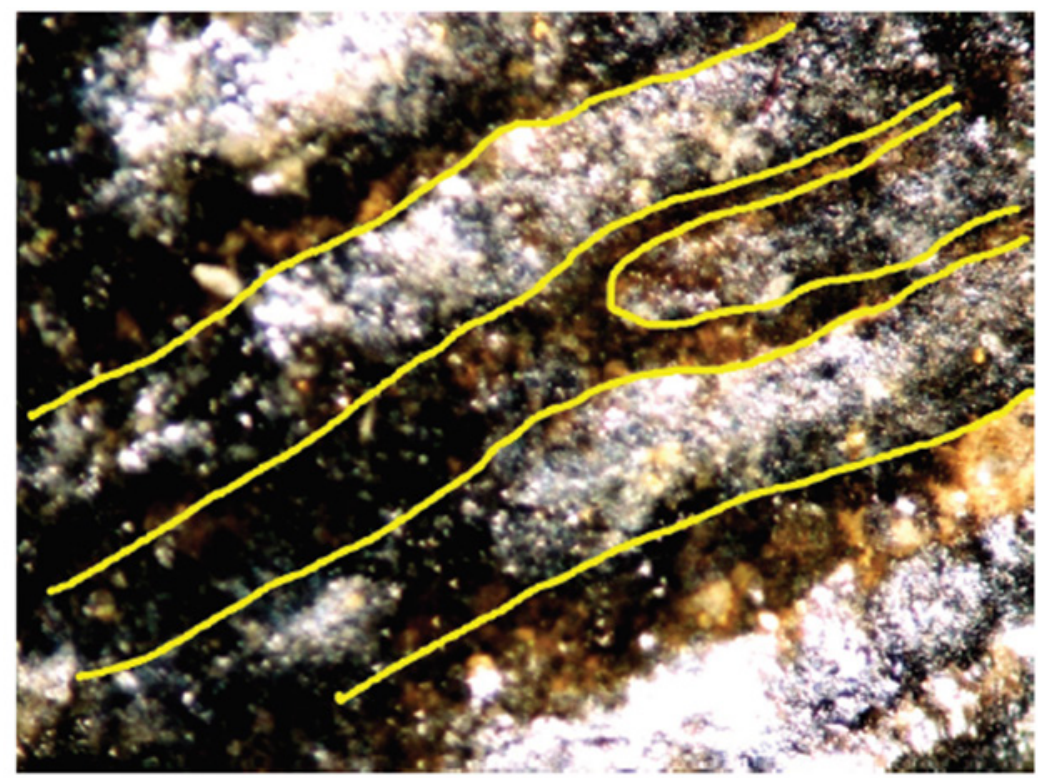

Fig. 14. Minutia on the back of the VěstoniceVenus; highlighting of ridges (Králík et al. 2002).

In the next research stage, the average width of the ridges was used in orderto determine the age of the individual to whom the imprint left on the figurine belonged. The analysis showed that the average width of the ridges was $0.37 \mathrm{~mm}$, with a standard deviation of $0.029 \mathrm{~mm}$. Taking into account the condition of the figure before the shrinkage of the ceramic material /clay, which shrinks during drying and firing - by an average of $7.5 \%$ ), the average width of the ridge 
amounts were $0.40 \mathrm{~mm}$, with a standard deviation of $0.031 \mathrm{~mm}$. Using the equation, proposed by Kamp et al. (1999), to calculate the average width of the ridges, $: y=614 x-112$ (y - age in months, $\mathrm{x}$ - lamella width in $\mathrm{mm}$ ), the age of the individual was estimated at 11.13 years. Experiments have shown that this type of age estimation deviates from the actual age by only 1.9 years, with a standard deviation of 1.36 years. The majority of estimates never differ by more than 4 years from the actual age. Therefore, it can be concluded that the person whose imprint was found on the figurine was between 7 and 15 years old. If the correlation between the width of the ridges and the age was the same in the Upper Paleolithic times as it is now, it becomes obvious that the print could not have belonged to an adult male. With more accuracy and with respect to the shrinkage of the ceramic material, the age estimation can be shifted more towards adulthood. This allows the possibility that the imprint was left by a young adolescent woman, or even a young adult woman. Morover, the study of Kralik et al. (2002) also shows, that the accurate age estimations are not possible for fingerprints. The study also mentions that sex assessment from fragmented fingerprints is impossible.

\section{Conclusion}

The above examples, both the author's own research and those cited, show how the analysis of the average width of the skin ridges can be used in archaeological research. As the average width of the ridges varies with the age of an individual, it can be argued that the average width of the ridges correlates with age. Taking into account the research on dermato- glyphs, the average width of the ridges and possibly the estimated age, conclusions can also be drawn about the sex of the individual who left his imprint on the vessel or material. Therefore, as these measurements are used to determine the sex and age of a person, it is useful not only in forensic research, but also in the case of archaeological studies; for example, in determining who was the craftsman of a given vessel or tool. However, it is important to remember that some studies also show serious limitations of such methods. The accurate estimation of age may not always be possible for fingerprints due to many different factors including shrinkage of the ceramic material, limited number of imprints, poor preservation of the imprints. Furthermore, it is also not possible to determine the sex of the owner's imprints from fragmented fingerprints.

\section{Conflict of interests}

Authors declare none conflict of interests

\section{Akcnowledgement}

This publication was financed by the Minister of Science and Higher Education (Grant No DNK/SP/463728/2020): Excellent Science - Support for scientific conferences. Funeralia Gnieźnieńskie Man in the perspective of interdisciplinary research.

\section{Corresponding author}

Daria Gromnicka, Department of Anthropology, Institute of Environmental Biology, Wrocław University of Environmental and Life Sciences, Kleczkowska St. 22/7, 50-227, Wrocław, Poland. E-mail: daria.gromnicka@gmail.com 


\section{References}

Alcaraz-Fossoul J, Mancenido M, Soignard E, Silverman N. 2018. Application of 3D Imaging Technology to Latent Fingermark Aging Studies. J Forensic Sci 64(2):570-6. https://doi.org/10.1111/15564029.13891

Białek I, Rodzińska-Nowak J. 2006. Ślady linii papilarnych na ceramice $z$ okresu wpływów rzymskich z osady kultury przeworskiej w Jakuszowicach, stan.2, gm. Kazimierza Wielkiego, woj. Świętokrzyskie. In: J Rodzińska-Nowak, editor. Jakuszowice stanowisko 2. Ceramika z osady kultury przeworskiej z młodszego I późnego okresu wpływów rzymskich I wczesnej fazy okresu wędrówek ludów. Zeszyty Naukowe Uniwersytetu Jagiellońskiego, Prace Archeologiczne 61, Kraków, Uniwersytet Jagielloński, Instytut Archeologii.

Fauld H. 1923. A Manual of Practical Dactylography. "Police review" publishing Company, Limited.

Galton F. 1893. Identification. letter in Nature 48:222. https://doi.org/10.1038/048222a0

Grzeszyk C. 1992. Daktyloskopia. Warszawa: PWN.

Kamp KA, Timmerman N, Lind G, Graybill J, Natowsky I. 1999. Discovering Childhood: Using Fingerprints to Find Children in the Archaeological Record. American Antiquity 64(2):309-15. https://doi. org/10.2307/2694281

Králík M, Novotný V, Oliva M. 2002. Fingerprint on The Venus of Dolní Věstonice I. Anthropologie 40(2):107-13.
Machhout M. 2017. Improvement of the Fingerprint Recognition Process. International Journal on Bioinformatics \& Biosciences 7(2):1-16. https://doi.org/10.5121/ ijbb.2017.7201

Montagna W, Parakkal PF. 1974.The structure of the skin. New York and London: Academic Press.

Moszczyński J. 1997. Daktyloskopia zarys teorii i praktyki. Warszawa: Wydawnictwo Centralnego Laboratorium Kryminalistycznego KGP w Warszawie.

Shier D, Butler J, Lewis R. 2010. Hole's Human Anatomy and Physiology. New York: McGraw-Hill.

Stolarek J. 2008. Identyfikacja użytkownika na podstawie analizy linii papilarnych. [In Polish]. Thesis. Politechnika Łódzka.

Szczepański T. 2019. Dactyloscopyover the centuries. Issues of Forensic Science 303(1):47-54. https://doi.org/10.34836/ pk.2019.303.2

Wałecki B. 2019. Przydatność odcisków stóp i dłoni na średniowiecznej i nowożytnej ceramice budowlanej do oceny organizacji i warunków pracy rzemieślników [In Polish]. Master thesis. Wrocław, Uniwersytet Przyrodniczy we Wrocławiu.

Wooi K, Man Lau W. 2015. skin deep: the basics of human skin structure and drugpenetration. Percutaneous Penetration Enhancers Chemical Methods in Penetration Enhancement. Berlin: Springer.

Wójcik A, Rogoża E, Drzewiecka K, Wudarczyk M. 2014. Fingerprinting and improvement of the readability of the fingerprints of corpses. Problemy Kryminalistyki 286(4):86-91. https://doi.org/10.34836/pk.2014.286.8 